Nicole Barrière, poète engagée, militante pour les valeurs humaines, la paix et la liberté. Elle défend en particulier la cause des femmes afghanes et la lutte pour la démocratie. Publications récentes : Et si ceétait elle (L'Harmattan, 2007); Trapèze sur le sable (Les Presses littéraires, 2006); Mamnu' (Editions Poèmes en gros et $1 \frac{1}{2}$ gros, 2005); Les ombres et le feu (L'Harmattan, 2004); Les ombres de Kaboul, impressions afghanes (Editions Poèmes en gros et $1 \frac{1}{2}$ gros, 2004).

\title{
国
}

\section{2ème jour de guerre}

I nquiétude aujourd'hui

Pourquoi m'as-tu distraite

De liens plus importants

Je sondais mes illusions

Toi, les mêmes, à-peu-près

Le poème inchangé de la peur

La phrase déformée, le masque

Ses abandons

Ses nuits insomniaques

Ses traits de lune.

Sale guerre

Encore une sale guerre

Nous résistons une fois encore

Mais mal

Nous voulons échapper dans le calme matin

Aux combats, à l'acharnement de fragments des uns contre les autres

Nous voulons penser entre deux effondrements à une justice possible

Et notre âge saigne jusqu'à l'écarlate des silences

Il y a un affolement de la terre

Les tirs entre les ruines 
Ecoute, la ville

Les raids aériens

Elle meurt entre deux ponts

Ecoute la ville

Elle s'épuise de l'exode

Ses habitants implorent

Bras ouverts comme de grands oiseaux meurtris

La ville est figée dans le silence

Entre les rideaux de fer

Les béances

Les décombres

Les blocs de béton sont des tombeaux ouverts

Le soir, la nuit, on craint la mort qui fait route jusqu'à l'aube

Le soir, la nuit, on cherche abri dans l'ombre de l'inquiétude

Trop de pensées peuplent le crépuscule des mots

Trop de rêves anéantis sont troués par le feu

Qui dira la peur traversée par le feu

Qui dira l'effroi dans tes yeux?

Qui dira ce passage de patrouille dans le cœur

Et l'ordre de tuer

La mort contemporaine

La folie rejointe par le vent coupable de l'horreur

La jonction des silences

L'invention du noir

La terre est remplie de violence

Le déluge de feu détruit la terre

Le déluge de vingt-deux jours de feu

Feu sur la terre

Feu dans les airs

Feu jusqu'aux limites du ciel

Feu dans chaque espace respiré

Feu dans chaque envol d'ailes

Les sources de l'enfer intarissables

De ce feu, de ce feu

Intarissable

Ce 22ème jour de feu 
Mon ange, mon enfant

Tes mains se tendent égarées

Le battement de ton cœur

Son appel fait mal

Ton baiser s'enflamme de terreur

Tes yeux figés dans la demeure des étoiles

$(02 / 08 / 2006)$ 